\title{
Antiemetic Activity of Trigona spp. Propolis from Three Provinces of Indonesia with Two Methods of Extraction
}

\author{
Al Mukhlas Fikri' ${ }^{1}$, Ahmad Sulaeman ${ }^{1 *}$, Sri Anna Marliyati ${ }^{1}$, Mokhamad Fahrudin ${ }^{2}$
}

\section{Al Mukhlas Fikri' ${ }^{1}$, Ahmad Sulaeman ${ }^{1 *}$, Sri Anna Marliyati ${ }^{1}$, Mokhamad Fahrudin ${ }^{2}$}

'Department of Community Nutrition, Faculty of Human Ecology, Bogor Agricultural University, Bogor 16680, INDONESIA.

${ }^{2}$ Faculty of Veterinary Medicine, Bogor Agricultural University, Bogor 16680, INDONESIA.

\section{Correspondence}

Ahmad Sulaeman

Department of Community Nutrition, Faculty of Human Ecology, Bogor Agricultural University, Bogor 16680, INDONESIA.

Phone no: +625775264968

E-mail: asulaema06@gmail.com

History

- Submission Date: 02-10-17;

- Review completed: 27-10-17;

- Accepted Date: 20-11-17

DOI : 10.5530/pj.2018.1.21

Article Available online

http://www.phcogj.com/v10/i1

Copyright

(C) 2018 Phcog.Net. This is an openaccess article distributed under the terms of the Creative Commons Attribution 4.0 International license.

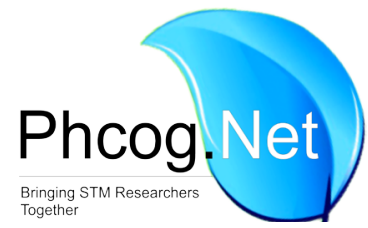

\begin{abstract}
Introduction: Propolis is a resinous substance collected by bees to protect their hives. One of the least explored function of propolis is its antiemetic activity. The present study aimed to investigate the antiemetic activity of Trigona spp. propolis from three provinces of Indonesia. Methods: Ultrasound-assisted extraction using two kinds of solvent, water and ethanol was conducted to extract propolis from South Sulawesi, South Kalimantan and Banten. Antiemetic activity was observed on copper sulfate-induced emesis in young chicks. Result: All propolis indicated antiemetic activity, in which water extract had higher activity than ethanol extract. Regardless the type of solvents, propolis from South Sulawesi showed higher antiemetic activity than others. Conclusion: This study demonstrated that propolis has antiemetic activity, in which propolis from South Sulawesi showed the highest activity and water extraction is recommended.
\end{abstract}

Key words: Antiemetic, Propolis, Retching, Stingless bee, Trigona spp.

\section{INTRODUCTION}

Propolis is a resinous substance collected by bees from various plants for its adaptation and honeycomb construction. ${ }^{1}$ It is the generic name of substance that protects the bees from unexpected environmental threats. Propolis acts as sealer and excluder for the honeycomb. ${ }^{2,3}$ Propolis also ensures smooth, moist and pleasant hives. ${ }^{4}$

Propolis is a potential substance that could improve our health. It is considered by many researchers as a new drug. ${ }^{5}$ Various functions of propolis have been widely investigated either by in vitro or in vivo assay. Some functions confirmed are; as antibacterial, antiviral, antifungal, anticancer, immunomodulatory, antiinflammatory, and antioxidant agents. ${ }^{6}$

Beside of those functions, there is also a less explored biological activity of propolis, which is as antiemetic. Study by Eda and colleagues is the first article to confirm the antiemetic effect from Brazilian propolis. They found $50.9 \%$ of retching inhibition in young chick emesis model treated with Brazilian Propolis. ${ }^{7}$ They also investigated several compounds (dehydrohautriwaic acid, propenoic acid, aromadandrane and dihydrocinamic acid) which are the basis of antiemetic activity of Brazilian propolis.

However, propolis properties tend to be inconsistent. It depends on its origins, seasons and plant sources. ${ }^{8,9}$ The previous study confirmed the diversity of Indonesian propolis compounds. ${ }^{10}$ The huge diversity of Indonesian propolis has made it generally considered as miscellaneous. In addition, solvent is also a crucial factor that influences propolis biological activity. However, there are conflicting result on types of solvent used to generate highest biological activity. Some studies found ethanol extract had higher antioxidant activity and total phenol compared to water extract. While, some other found water is a better solvent to generate high antioxidant activity and total phenol. ${ }^{11,12,13}$ This study aimed to investigate the antiemetic activity of propolis from three provinces of Indonesia, using two types of solvent (ethanol and water). We applied ultrasound-assisted extraction to yield more efficient and effective extract. ${ }^{14}$

\section{MATERIALS AND METHOD}

\section{Materials}

Raw propolis were collected by bee-keeper in South Sulawesi, South Kalimantan and Banten. The species of bees were all stingless bees (Trigona spp.) namely Tetragonula biroi(South Kalimantan), HeteroTrigona itama (South Kalimantan) and Tetragonula laevicep (Banten). We used copper sulfate $\left(\mathrm{CuSO}_{4}\right)$ as emetogenic substance and metoclopramide as positive control. Dimethyl sulfoxide (DMSO) and Tween 80 were used as solvent for injected propolis.

\section{Animals}

The young chicks (aged 4 days) and weighing from 50-80 g were purchased from Cibadak Indah Sari Farm, Jakarta, Indonesia. All animal experiments were carried out in accordance with the acts of The

Cite this article: Fikri AM, Sulaeman A, Marliyati SA, Fahrudin M. Antiemetic Activity of Trigona spp. Propolis from Three Provinces of Indonesia with Two Methods of Extraction. Pharmacog J. 2018;10(1):120-2. 
Ethical Committee of Institute of Research and Community Services of Bogor Agricultural University (No. 64-2017IPB).

\section{Preparation of extract}

The extracts were prepared using ethanol and water extraction. It was carried out in a sonicator bath (Branson 2000). The wave increases cell permeability thus result in optimum solubility of the active component. ${ }^{15}$ The procedures refered to Trusheva method with slight modification. ${ }^{16}$ Raw propolis was added to solvents (1:10) then treated with ultrasound for $4 \mathrm{~h}$. Subsequently, propolis was filtered by what man No.41 and evaporated using vacuum evaporator.

\section{Antiemetic activity assay}

The young chicks were divided into 8 groups of treatments, 4 chicks in each group. They were set aside for $10 \mathrm{~min}$ for stabilization before any treatment was given. The groups of treatments were; water extract of propolis from South Sulawesi (WS), South Kalimantan (WK), Banten (WB), ethanol extract of propolis from South Sulawesi (ES), South Kalimantan (EK) and Banten (EB), negative control (0.9\% saline) and positive control (metoclopramide). The extracted propolis sample were dissolved in $0.9 \%$ saline (containing $5 \%$ DMSO and $1 \%$ Tween 80 ) to create injection solution. Subsequently, $300 \mathrm{mg} / \mathrm{kg}$ of propolis was injected abdominally. 10 minutes post injection, $\mathrm{CuSO}_{4}$ was then administered orally $(50 \mathrm{mg} / \mathrm{kg})$. The number of retching was calculated for 10 min. ${ }^{7,17}$ The results were compared to control group. The percent of inhibition was calculated by the following formula:

$$
\text { Inhibition }(\%)=[(\mathrm{A}-\mathrm{B}) / \mathrm{A}] \times 100
$$

A: Frequency of retching in negative control group

B: Frequency of retching in tested group

\section{Statistical analysis}

Number of retching was expressed as mean \pm SEM. The difference was determined by univariate analysis of variance and considered to be significant when $p<0.05$.

\section{RESULT}

Our present study showed that all propolis possess antiemetic activity. Propolis ES, WS, WB and WK were not significantly different in the number of retching to control (+). The inhibition ranged from 44.96 up to $98.51 \%$ (Table 1). For ethanol extract, propolis from South Sulawesi had the highest retching inhibition. While for water extract, all kinds of propolis were not significantly different to control $(+)$.

According to univariate analysis of variance, both the solvents and origins of propolis had significant effect on antiemetic activity $(\mathrm{p}=0.001$, respectively). Regardless the type of solvents, propolis from South Sulawesi had the highest inhibition power compared to the others and water extract had higher inhibition power than ethanol extract for all propolis origins.

\section{DISCUSSION}

Emesis, nausea and/or vomiting, is an unpleasant state which is a manifestation of several conditions including pregnancy, toxicants ingestion, and side effect of medication, surgery and cancer chemotheraphy. ${ }^{18}$ Emesis could lead to loss of appetite, fluid and electrolyte disturbance, and decreased nutritional status. ${ }^{19,20}$

Propolis works as antiemetic through several mechanisms. Hydroxycinamic acids of propolis act as $\delta$ (enkephalinergic)-receptor antagonist and inhibit dopamine receptor. Propolis also contains tritepens which are $5-\mathrm{HT}_{3}, 5-\mathrm{HT}_{4}$ and/or $\mathrm{NK}_{1}$ receptors antagonist. These receptors are involved in emesis stimulation. ${ }^{21}$ Our research supports the previous study about the antiemetic activity of Brazilian propolis. ${ }^{7}$ The study also
Table 1: Antiemetic activity of Trigona spp propolis.

\begin{tabular}{ccccc}
\hline Origin of Propolis & Solvent & Code & No. Retching & Inhibition (\%) \\
\hline Banten & Ethanol & EB & $102.50 \pm 3.45^{\mathrm{b}}$ & 49.17 \\
Banten & Water & WB & $6.00 \pm 0.44^{\mathrm{a}}$ & 97.02 \\
South Sulawesi & Ethanol & ES & $8.75 \pm 0.72^{\mathrm{a}}$ & 95.66 \\
South Sulawesi & Water & WS & $3.00 \pm 0.37^{\mathrm{a}}$ & 98.51 \\
South Kalimantan & Ethanol & EK & $111.00 \pm 3.37^{\mathrm{b}}$ & 44.96 \\
South Kalimantan & Water & WK & $16.50 \pm 2.38^{\mathrm{a}}$ & 91.82 \\
Control (+) & & & $2.75 \pm 0.40^{\mathrm{a}}$ & 98.64 \\
Control (-) & & & $201.67 \pm 2.69^{\mathrm{c}}$ & - \\
\hline
\end{tabular}

*Values in the same column followed by the same uppercased letter are not significantly significant $(\mathrm{p}<0.05)$

EB : Ethanol extract of propolis from Banten

WB : Water extract of propolis from Banten

ES : Ethanol extract of propolis from South Sulawesi

WS : Water extract of propolis from South Sulawesi

EK : Ethanol extract of propolis from South Kalimantan

WK : Water extract of propolis from South Kalimantan

found water extract of Brazilian propolis demonstrated higher antiemetic activity than hydro alcohol extract. The reason is still unclear. However, it is suspected that there are other water soluble compounds, such as glucoside, polysaccharides, saponins that work as inhibitor of some emesis receptors. ${ }^{22}$

Some experimental animals have been widely developed as an emetic model such as: ferret, mink, monkey, pig, rat, frog, dog and chick. ${ }^{23}$ Chick as emesis animal model has been used by many researchers.,17,24,25,26 These model is better than frog emesis model because it has some advantages such as, easy to handle and able to visually observed and required shorter time. ${ }^{26}$

$\mathrm{CuSO}_{4}$-induced chicks emesis model are suitable for screening for the potency of product as antiemesis. ${ }^{17} \mathrm{CuSO}_{4}$ induces emesis through direct stimulation of the stomach wall (gastric irritation) and/or through 5-HT4 stimulation. ${ }^{22}$ Those are the part of mechanisms that participate in nausea and vomiting action. In addition, this model is also suitable for evaluating brain participation in emerging emesis. ${ }^{23}$

\section{CONCLUSION}

Our results demonstrated that Indonesian propolis has antiemetic activity, in which propolis from South Sulawesi has indicated the highest activity. Water extracts have shown higher activity compared to the ethanol extract thus we recommend water extraction for generating higher antiemetic activity.

\section{ACKNOWLEDGEMENT}

We wish to thank the Ministry of Research Technology and Higher Education of the Republic of Indonesia that funded this research.

\section{CONFLICT OF INTEREST}

We have no conflict of intereset to disclose.

\section{REFERENCES}

1. Bankova VS, De Castro SL, Marcuccci MC. Propolis: recent advances in chemistry and plant origin. Apidologie. 2000;31(1):3-15.

2. Mohammadzadeh S, Shariatpanahi M, Hamedi M, Ahmadkhaniha R, Samadi N, Ostad SN. Chemical composition, oral toxicity and antimicrobial activity of Iranian propolis. Food Chemistry. 2007;103(4):1097-103. 
3. Menniti-Ippolito F, Mazzanti G, Vitalone A, Firenzuoli F, Santuccio C. Surveillance of suspected adverse reaction to natural health products, the case of propolis. Drug Safety. 2008;31(5):419-23.

4. Huang S, Zhuang C, Wang K, Li QG, Hu F. Recent advances in the chemical composition of propolis. Molecules. 2014;19(12):19610-32.

5. Sforcin JM, Bankova V. Propolis: Is there a potential for the development of new drugs. Journal of Ethnopharmacology. 2011;133(2):253-60.

6. Król W, Bankova V, Sforcin JM, Szliszka E, Czuba Z, K.Kuropatnicki A. Propolis: properties, application, and its potential [editorial]. Evidence-Based Complementary and Alternatives Medicine. 2013.

7. Eda M, Hayashi Y, Kinoshita K, Koyama K, Takashi K, Akutu K. Anti-emetic principles of water extract of Brazilian propolis. Pharmaceutical biology. 2005;43(2):184-8.

8. Lofty M. Biological activity of bee propolis in health and disease. Asian Pac Journal of Cancer Prevention. 2006;7(1):22-31.

9. Salatino A, Teixeira ÉW, Negri G, Message D. Origin and chemical variation of Brazilian propolis. Evidence-Based Complementary and Alternative Medicine. 2005;2(1):33-8.

10. Kalsum N, Sulaeman A, Setiawan B, Wibawan IWT. Phytochemical profiles of propolis Trigonas spp. from three regions in Indonesia using GC-MS. Journal of Biology, Agriculture and Healthcare. 2016;6(14):31-7.

11. Sun $C$, Wu Z, Wang Z, Zhang $H$. Effect of ethanol/water solvents on phenolic profiles and antioxidant properties of Beijing Propolis Extracts. Evidence-Based Complementary and Alternative Medicine. 2015;1-9.

12. Mello BCBS, Petrus JCC, Hubinger MD. Concentration of flavonoids and phenolic compounds in aqueous and ethanolic propolis extracts through nanofiltration. Journal of Food Engineering. 2010;96(4):533-9.

13. Laskar AR, Sk I, Roy N, Begum AN. Antioxidant activity of Indian propolis and its chemical constituents. Food Chemistry. 2010;122(1):233-7.

14. Liu W, Wang $X$. Extraction of flavone analogues from propolis with ultrasound. Food Science (Chines). 2004;25:35-9

15. Deore LS, Baviskar AB, Rangari SA. Rapid and high yield extraction method for saponins from Safed musli. Pharmacognosy Journal. 2015;7(4):201-14.

16. Trusheva B, Trunkova D, Bankova V. Different extraction methods of biologically active components from propolis: a prelimninary study. Chemistry Central Journal 2013:1(13):1-4.

17. Ahmed S, Meer S. Anti-emetic activity of four species of genus Cassia in chicks. IOSR Journal of Pharmacy. 2012;2(3):380-4.

18. Hussain M, Raza MS, Khan RM, Nawaz S. In vivo assessment of antiemetic potential of crude extract of Vetiveria zizanioides (Linn); chick emesis model. International Journal of Pharma Sciences. 2015;5(3):1068-71.

19. Jewel D. Nausea and vomiting in early pregnancy. Clinical Evidence. 2003;9:1561-70

20. Wezel-Meijer G, Wit JM. The offspring of mothers with anorexia nervosa: a high-risk group for under nutrition and stunting? European Journal of Pediatrics. 1989;149(2):130-5.

21. Ahmed S, Hasan MM, Ahmed W. Natural antiemetics: an overview. Pakistan Journal of Pharmaceutical Sciences. 2015;27(5):1583-98.

22. Ahmed S, Hasan MM, Ahmed SW, Mahmood ZA, Azhar I, Habtemariam S. Antiemetic effects of biactive natural products. Phytopharmacology. 2013;4(2):390-433.

23. Tijani AY, Okhale SE, Oga FE, Tags SZ, Salawu OA, Chindo BA. Antiemetic activity of Grewia lasiodiscus root extract and fractions. African Journal of Biotechnology. 2008;7(17):3011-6

24. Yang Y, Kinoshita K, Koyama K, Takashi K, Takaaki T, Nunoura Y, et al. Novel experimental model using free radical-induced emesis for surveying anti-emetic compounds from natural sources. Planta Med. 1999;65(6)574-6.

25. Akita Y, Yang Y, Kawai T, Kinoshita K, Koyama K, Takahashi K, et al. New assay method for surveying anti-emetic compounds from natural sources. Natural Product Sciences. 1998;4(2):72-7.

26. Husseinzadeh H, Mirshojaeian, Razavi BM. Antiemetic effect of Pistacia vera L. (Pistachio) leaves and nuts aqueous extracts in young chicken. Pharmacology online. 2008:2(2008):568-71.

\section{GRAPHICAL ABSTRACT}

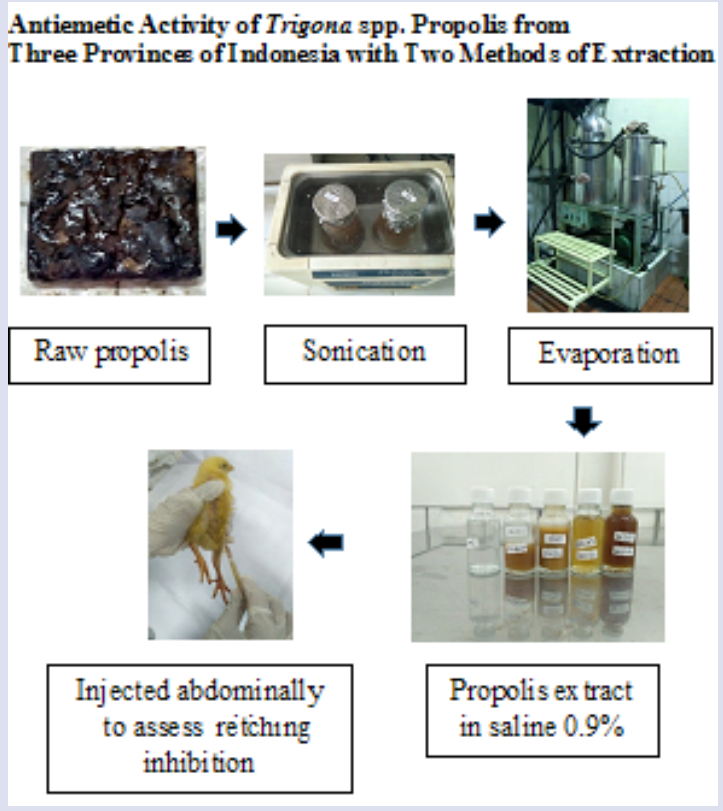

\section{SUMMARY}

- Indonesian propolis shows antiemetic activity, in which propolis from South Sulawesi indicates the highest activity.

- Water extracts have shown higher activity compared to the ethanol extract.

\section{ABOUT AUTHORS}

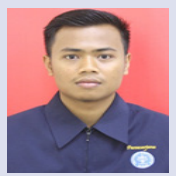

Al Mukhlas Fikri, A Doctoral student of Department of Community Nutrition, Faculty of Human Ecology, Bogor Agricultural University, Indonesia. The doctoral research focuses on proplis as antiemtic agent and its toxicity level.

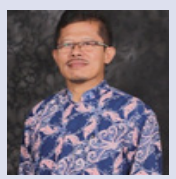

Ahmad Sulaeman, a Professor at Department of Community Nutrition, Faculty of Human Ecology, Bogor Agricultural University, Indoensia. His reseaches focus on food safety and nutrition.

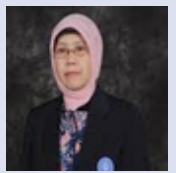

Sri Anna Marliyati, a Doctor at Departement of Community Nutrition, Faculty of Human Ecology, Bogor Agricultural University, Indonesia. She is the expert in food science and dietetics.

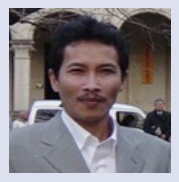

Mokhamad Fahrudin, a Veterinarian who works at Faculty of Veterinary Medicine, Bogor Agricultural University, Indonesia. He is the expert in embriology and fetal development.

Cite this article: Fikri AM, Sulaeman A, Marliyati SA, Fahrudin M. Antiemetic Activity of Trigona spp. Propolis from Three Provinces of Indonesia with Two Methods of Extraction. Pharmacog J. 2018;10(1):120-2. 